\title{
Tourist Expectation and Perception towards Service Quality of Tourism Services in Kodaikanal
}

\author{
D. Manimekalai
}

\begin{abstract}
Tourism refers to movement of one place to another place. its generates more revenue to Government. Tourism develops other associated industries like Hotel industry, transport, handicraft and travel agent. Tourism in India is the largest service and one of the most profitable industries in the country.

Kodaikanal is one of the very popular and most sought holiday destination hill resorts in South India. The economy of Kodaikanal is predominantly run by tourism. The number of tourists increased year by year. Service providers who are related to tourism services are also increases. They provide lot of services to their customers and try to satisfy them. Hence, it has created an initiative to the researcher to study service quality of the tourism services.
\end{abstract}

Keywords: tourism, kodaikanal, service quality, sustainable development, perception

\section{INTRODUCTION}

Today, tourism is a major service industry which contributes more to one countries national income and also its growth. Tourism refers to movement of one place to another place, it may be travel to historical importance places, hilly stations etc for the purpose of relaxation, education, sports, medical etc., every year a travel to another country or within the country is increased and its generates more revenue to Government. Tourism develops other associated industries like Hotel industry, transport, handicraft and travel agent.

Tourism brings in large amounts of earnings into a local economy in the form of payment for goods and services needed for tourists, accounting for $30 \%$ of the world's trade of services, and $6 \%$ of overall exports of goods and services. It also creates a platform for employment in the service sector of the economy associated with Tourism. The World Tourism and Travel Council (WTTC) estimates that the total contribution of travel and tourism would be Rs.14722.3 billion (7.9 per cent of GDP) in 2023. ${ }^{1}$ By its importance tourism is recognized as an "Industry".

\section{TOURISM IN INDIA}

Tourism in India is the largest service and one of the most profitable industries in the country. According to the World Travel \& Tourism Council report2, International tourist arrivals to India are expected to touch 13.43 million by 2024 .

Revised Manuscript Received on December 05, 2019.

Dr. D. Manimekalai, Assistant Professor, Department of Commerce (CS) Ayya Nadar Janaki Ammal College of Arts \& Science, Sivakasi, India. E-mail: manimekalaidhanasekaran@gmail.com

\footnotetext{
${ }^{1}$ Opportunities in Tourism, Hospitality and Event Management, Journal of the Federation of Andhra Pradesh Chambers of Commerce and Industry, Vol.XIII, No.15, April 10, 2013, p.1. (1-10).

2 World Travel \& Tourism Council report, retrieved from https://www.wttc.org/-/.../reports
}

Expenditure by foreign tourists in India is expected to grow $4.3 \%$ every year to Rs 1.74 lakh crore in 2024 . It provides substantial foreign exchange and jobs. According to Government of India estimate, every one Crore Rupee invested in Tourism creates 475 jobs as against 126 jobs from Manufacturing Sector.

\section{STATEMENT OF THE PROBLEM}

Kodaikanal is one of the very popular and most sought holiday destination hill resorts in South India. The economy of Kodaikanal is predominantly run by tourism. The number of tourists increased from two million in 1999 to 3.2 million in 2009, 4.2 million in 2013 and 5.3 million in 2015. With the development of modern amenities and transport Kodaikanal has become one of the favourite summer destinations to the tourists, however, many local tourist groups commute on short trips to Kodaikanal. With the increasing trend of tourist towards Kodaikanal leads to the growth of large number of service providers. They provide lot of services to their customers and try to satisfy them. Hence, it has created an initiative to the researcher to study service quality of the tourism services.

\section{OBJECTIVES OF THE STUDY}

The main objectives of the study are:

1. To study about the socio-economic profile of Tourist

2. To find out service facilities available in Kodaikanal

3. To analyze the tourists perception towards service facilities

4. To evaluate the tourists expectation towards service facilities

5. To measure the level of satisfaction towards service facilities

6. To find out the gap between perception and expectation with regards to tourism services

7. To identify the Impediments faced by the respondents in Kodaikanal and offer suggestions based on the findings for sustaining of tourism services

\section{SCOPE OF THE STUDY}

This study is confined to tourist (both domestic and International tourists) who are visiting Kodaikanal and their opinion towards tourism services offered and so the research scope is limited, and more specifically, it is associated with tourism. 


\section{RESEARCH METHODOLOGY} here under

The methodology of the present study is outlined

Population - Population for selecting sample units of the study includes tourist both Domestic and International Tourists who visit Kodaikanal.

Sampling Technique - Purposive random sampling technique is used.

Sample Size - In this study, the researcher took 536 samples from the population.

Source and Tool for Data Collection - In this study both primary and secondary data were used. The primary data is collected through a well structured questionnaire. The Questionnaire is constructed on the basis of REQUAL Model. The Secondary Data were collected from Magazines, Books, Journals, Tourism Office, Government Reports and Statistics, Websites etc.,

\section{Tools for Analysis}

The various statistical tools used in this study are simple percentage analysis, Standard Deviation, Weighted average, Chi-square test, Analysis of variance, Garrett ranking analysis, Inter Correlation and Multiple Regression Analysis, T-Test, Descriptive analysis and Gap Analysis.

\section{LIMITATIONS OF THE STUDY}

The limitations of this study are,

1. The study is confined to Kodaikanal only.

2. Since it is an empirical study, there may be personal bias in getting the data where the respondents may be reluctant to provide some of the information.

3. The findings cannot be generalized to the universe.

\section{LITERATURE REVIEW}

Jacob Konwar \& Deb Kr.Chakraborty $(2015)^{3}$, pointed that there is a significant mean difference in the opinions of the domestic and foreign visitors regarding the tourism related products and services in the river island Majuli before and after visiting it.

Mahamad S, Latha G, Manikandan N \& Chandrasekar V (2014) ${ }^{4}$ rightly pointed out that tourism has played a very decisive role to transform the world into a globalized economy where all nations can exchange free trade and culture and share their interest of mutual benefits based on tourism industry.

Thilakam.C \& Jothimani. U (2014) ${ }^{5}$, suggested that the government authorities should take necessary step to

\footnotetext{
3 Jacob Konwar \& Deb Kr.Chakraborty, "Tourism and its associated aspects in the River Island Majuli, Assam: A Study from the Perspective of Visitors", Prabandhan: Indian Journal of Management, July 2015, pp. $41-50$

${ }^{4}$ Mahamad S, Latha G, Manikandan N \& Chandrasekar V, "A study of tourist inflow in Tamilnadu 2001-2012 - A GIS based study", International Journal of Geomatics and Geosciences, Vol. 5, Issue 2, 2014, pp - $312-319$.

${ }^{5}$ Thilakam .C \& Jothimani. U," A Study on Consumer Attitude towards Tourism Products in Tuticorin District", Ph.D thesis submitted to Manonmaniam Sundaranar University, Oct 09, 2014, retrieved from
}

boost the quality of the hospitality services provided in the study area. A list of approved hotels and their rates, facilities and types of meals offered, $\neg$ telephone number with emails their location and taxi charges from station should also be included in the travel brochures.

\section{SOCIO - ECONOMIC PROFILE}

The data collected through questionnaire are indicated in the upcoming table.

Table - 1- Socio Economic Profile

\begin{tabular}{|c|c|c|c|}
\hline \multicolumn{2}{|c|}{ Socio-Economic Factors } & \multirow{2}{*}{\begin{tabular}{|c|} 
Frequency \\
254
\end{tabular}} & \multirow{2}{*}{$\begin{array}{c}\text { Percent } \\
47.4\end{array}$} \\
\hline Gender & Male & & \\
\hline Gง & Female & 282 & 52.6 \\
\hline \multirow{5}{*}{ Age } & $18-20$ & 80 & 14.9 \\
\hline & $21-25$ & 131 & 24.4 \\
\hline & $26-30$ & 126 & 23.5 \\
\hline & $31-35$ & 60 & 11.2 \\
\hline & $36-40$ & 108 & 20.2 \\
\hline \multirow{4}{*}{ Marital Status } & Unmarried & 192 & 35.8 \\
\hline & Married & 296 & 55.2 \\
\hline & Separated & 32 & 6.0 \\
\hline & Widow & 16 & 3.0 \\
\hline \multirow{5}{*}{$\begin{array}{l}\text { Educational } \\
\text { Qualification }\end{array}$} & Up to SSLC & 30 & 5.6 \\
\hline & HSC & 94 & 17.5 \\
\hline & Graduation & 283 & 52.8 \\
\hline & Diploma & 65 & 12.2 \\
\hline & Others & 64 & 11.9 \\
\hline \multirow{4}{*}{$\begin{array}{c}\text { Employment } \\
\text { Status }\end{array}$} & Homemaker & 43 & 8.0 \\
\hline & Service & 87 & 16.3 \\
\hline & Own Business & 177 & 33.0 \\
\hline & Professional & 149 & 27.8 \\
\hline \multirow{4}{*}{ Monthly Income } & $\begin{array}{l}\text { Below Rs. } \\
10,000\end{array}$ & 30 & 5.6 \\
\hline & $\begin{array}{l}\text { Rs. } 10,001 \text { to } \\
\text { Rs. } 25,000\end{array}$ & 114 & 21.2 \\
\hline & $\begin{array}{l}\text { Rs. } 25,001 \text { to } \\
\text { Rs. } 50,000\end{array}$ & 181 & 33.8 \\
\hline & $\begin{array}{l}\text { Above Rs. } \\
50,000\end{array}$ & 211 & 39.4 \\
\hline \multirow{4}{*}{ Family Size } & Up to 2 & 109 & 20.3 \\
\hline & 3 to 4 & 269 & 50.2 \\
\hline & 5 to 6 & 110 & 20.5 \\
\hline & Above 6 & 48 & 9.0 \\
\hline
\end{tabular}

Source: Collected through Questionnaire

http://www.slideshare.net/UJothiMani/tourism - 40051899\#related-tab content 
From this study its revealed that, female are interested to visit kodaikanal as compared to male, youngsters who pertaining to the age group 21-25 and married people are eager to visit kodaikanal, further it should be noted that graduates are having interest as compared to other categories and families whose monthly income more than Rs.50,000 are plan to come kodaikanal.

Table - 2 - Pre- Tour Related Profile

\begin{tabular}{|l|l|c|c|}
\hline \multicolumn{2}{|c|}{ Tour related facts } & Frequency & Percent \\
\hline \multirow{3}{*}{ Nationality } & Indian & 388 & 72.4 \\
\cline { 2 - 4 } & Foreign Nationals & 148 & 27.6 \\
\hline \multirow{3}{*}{$\begin{array}{l}\text { Place of } \\
\text { origin }\end{array}$} & Within Tamil Nadu & 232 & 43.3 \\
\cline { 2 - 4 } & Other States of India & 121 & 22.6 \\
\hline
\end{tabular}

\begin{tabular}{|c|c|c|c|}
\hline \multicolumn{2}{|l|}{ Tour Plan } & \multirow{2}{*}{\begin{tabular}{|c|} 
Frequency \\
210
\end{tabular}} & \multirow{2}{*}{\begin{tabular}{|c|} 
Percent \\
39.2
\end{tabular}} \\
\hline \multirow{5}{*}{ Purpose of visit } & Site seeing & & \\
\hline & Mountaineering & 56 & 10.4 \\
\hline & Rest & 203 & 37.9 \\
\hline & Business & 42 & 7.8 \\
\hline & Education & 25 & 4.7 \\
\hline \multirow{5}{*}{ Length of Stay } & One day & 110 & 20.5 \\
\hline & Two days & 146 & 27.2 \\
\hline & Three days & 100 & 18.7 \\
\hline & Four days & 67 & 12.5 \\
\hline & $\begin{array}{l}\text { More than four } \\
\text { days }\end{array}$ & 113 & 21.1 \\
\hline \multirow{5}{*}{$\begin{array}{l}\text { Mode of } \\
\text { Transport }\end{array}$} & Own Vehicle & 189 & 35.3 \\
\hline & Hired Vehicle & 96 & 17.9 \\
\hline & $\begin{array}{l}\text { Common sight } \\
\text { seeing coach }\end{array}$ & 86 & 16.0 \\
\hline & Friend's Car & 60 & 11.2 \\
\hline & $\begin{array}{l}\text { Travel Agent } \\
\text { Vehicle }\end{array}$ & 105 & 19.6 \\
\hline \multirow{5}{*}{ Cost of travel } & Up to Rs. 10,000 & 94 & 17.5 \\
\hline & $\begin{array}{l}\text { Rs. } 10,001 \text { - Rs. } \\
20,000\end{array}$ & 137 & 25.6 \\
\hline & $\begin{array}{l}\text { Rs. } 20,001 \text { - Rs. } \\
30,000\end{array}$ & 127 & 23.7 \\
\hline & $\begin{array}{l}\text { Rs. } 30,001 \text { to Rs. } \\
40,000\end{array}$ & 50 & 9.3 \\
\hline & \multicolumn{2}{|c|}{ Above Rs. 40,000 128} & 23.9 \\
\hline \multirow{8}{*}{$\begin{array}{l}\text { No of times } \\
\text { visit }\end{array}$} & Union territory & 35 & 6.5 \\
\hline & European & 34 & 6.3 \\
\hline & American & 45 & 8.4 \\
\hline & Australian & 33 & 6.2 \\
\hline & Asian countries & 21 & 3.9 \\
\hline & African & 15 & -2.8 \\
\hline & Once & 192 & 35.8 \\
\hline & Twice & 183 & 34.1 \\
\hline
\end{tabular}

\begin{tabular}{|c|l|c|c|}
\multirow{4}{*}{$\begin{array}{c}\text { Factors } \\
\text { Influenced }\end{array}$} & Advertisements & 49 & 9.1 \\
\cline { 2 - 4 } & $\begin{array}{l}\text { Friends and } \\
\text { Relatives }\end{array}$ & 206 & 38.4 \\
\cline { 2 - 4 } & & & \\
\hline
\end{tabular}

\section{Source: Collected through Questionnaire}

The above table pointed out that, domestic tourist particularly people from Tamil nadu having more interest to visit kodaikanal and they came to know kodaikanal by friends and relatives. Further it indicates that the American travelers also paying attention to visit the beauty of kodaikanal and most of the tourist are first time visit the kodaikanal.

Table - 3 - Opinion about kodaikanal

\begin{tabular}{|c|c|c|c|}
\hline \multicolumn{2}{|c|}{ Opinion } & Frequency & Percent \\
\hline \multirow{3}{*}{ Outlook } & $\begin{array}{l}\text { Place of Scenic } \\
\text { beauty }\end{array}$ & 212 & 39.55 \\
\hline & $\begin{array}{l}\text { Good place for } \\
\text { resting and } \\
\text { peace }\end{array}$ & 114 & 21.27 \\
\hline & $\begin{array}{l}\text { Good place for } \\
\text { time pass }\end{array}$ & 210 & 39.17 \\
\hline \multirow{3}{*}{$\begin{array}{l}\text { Times } \\
\text { of visit }\end{array}$} & Season Time & 219 & 40.9 \\
\hline & Off Season & 209 & 39.0 \\
\hline & Festival Time & 108 & 20.1 \\
\hline
\end{tabular}

\section{Source: collected though Questionnaire}

This table shows that, most of the tourist felt that kodaikanal as a place of scenic beauty and they also willing to visit such places in seasonal time.

Table-4- Tour Plan

\section{Source: collected though Questionnaire}

From the above table it should be clear that, most of the tourist visit kodaikanal for sightseeing purpose and they plan to stay for two days. Majority of the tourist use their own Vechicle to seeing the places and their budgeted cost is Rs.10,001 to Rs.20,000. 
Table - 5-

Accommodation services \& Service Quality Perceived

\begin{tabular}{|l|c|c|l|}
\hline \multicolumn{1}{|c|}{$\begin{array}{c}\text { REQUAL } \\
\text { Factors }\end{array}$} & $\begin{array}{c}\text { Chi } \\
\text { Square } \\
\text { Value }\end{array}$ & P Value & $\begin{array}{l}\text { Significant } \\
\text { / Not } \\
\text { Significant }\end{array}$ \\
\hline Assurance & $8.682^{\mathrm{a}}$ & 0.013 & $\begin{array}{l}\text { Significan } \\
\text { t at } 5 \% \\
\text { level }\end{array}$ \\
\hline Reliability & $94.746^{\mathrm{a}}$ & 0.000 & $\begin{array}{l}\text { Significan } \\
\text { t at 1\% } \\
\text { level }\end{array}$ \\
\hline Responsiveness & $110.916^{\mathrm{a}}$ & 0.000 & $\begin{array}{l}\text { Significan } \\
\text { t at } 1 \% \\
\text { level }\end{array}$ \\
\hline Tangibles & $173.986^{\mathrm{a}}$ & 0.000 & $\begin{array}{l}\text { Significan } \\
\text { t at } 1 \% \\
\text { level }\end{array}$ \\
\hline $\begin{array}{l}\text { Service } \\
\text { Responsibility }\end{array}$ & $50.801^{\mathrm{a}}$ & 0.000 & $\begin{array}{l}\text { Significan } \\
\text { t at } 1 \% \\
\text { level }\end{array}$ \\
\hline $\begin{array}{l}\text { Service Product } \\
\text { Dimension }\end{array}$ & $100.031^{\mathrm{a}}$ & 0.000 & $\begin{array}{l}\text { Significan } \\
\text { t at } 1 \% \\
\text { level }\end{array}$ \\
\hline
\end{tabular}

Source: Computed from primary data

It is obviously identified that, there is a connection between overall satisfaction in Food and accommodation services with Reliability, Responsiveness, Tangibles, Service Responsibility and Service Product Dimension. Since $\mathrm{P}$ value is less than 0.01 , null hypothesis is rejected at $1 \%$ level of significance.

Table - 6-

Transport services \& Service Quality Perceived

\begin{tabular}{|l|c|c|l|}
\hline \multicolumn{1}{|c|}{$\begin{array}{c}\text { REQUAL } \\
\text { Factors }\end{array}$} & $\begin{array}{c}\text { Chi Square } \\
\text { Value }\end{array}$ & P Value & $\begin{array}{l}\text { Significant/ } \\
\text { Not } \\
\text { Significant }\end{array}$ \\
\hline Assurance & $47.581 \mathrm{a}$ & 0.000 & $\begin{array}{l}\text { Significant } \\
\text { at } 1 \% \\
\text { level }\end{array}$ \\
\hline Reliability & $43.892 \mathrm{a}$ & 0.000 & $\begin{array}{l}\text { Significant } \\
\text { at } 1 \% \\
\text { level }\end{array}$ \\
\hline Responsiveness & $137.555 \mathrm{a}$ & 0.000 & $\begin{array}{l}\text { Significant } \\
\text { at } 1 \% \\
\text { level }\end{array}$ \\
\hline Tangibles & $177.946 \mathrm{a}$ & 0.000 & $\begin{array}{l}\text { Significant } \\
\text { at } 1 \% \\
\text { level }\end{array}$ \\
\hline $\begin{array}{l}\text { Service } \\
\text { Responsibility }\end{array}$ & $181.806 \mathrm{a}$ & 0.000 & $\begin{array}{l}\text { Significant } \\
\text { at } 1 \% \\
\text { level }\end{array}$ \\
\hline $\begin{array}{l}\text { Service Product } \\
\text { Dimension }\end{array}$ & $208.438 \mathrm{a}$ & 0.000 & $\begin{array}{l}\text { Significant } \\
\text { at 1\% } \\
\text { level }\end{array}$ \\
\hline
\end{tabular}

\section{Source: Computed from primary data}

It is obviously identified that, there is a connection between overall satisfactions in Transport services with Assurance, Reliability, Responsiveness, Tangibles, Service Responsibility and Service Product Dimension.
Table - 7-

Travel Agent services \& Service Quality Perceived

\begin{tabular}{|l|c|c|c|}
\hline \multicolumn{1}{|c|}{$\begin{array}{c}\text { REQUAL } \\
\text { Factors }\end{array}$} & $\begin{array}{c}\text { Chi Square } \\
\text { Value }\end{array}$ & P Value & $\begin{array}{c}\text { Significant/ } \\
\text { Not } \\
\text { Significant }\end{array}$ \\
\hline Assurance & $178.542 \mathrm{a}$ & 0.000 & $\begin{array}{c}\text { Significant } \\
\text { at 1\% level }\end{array}$ \\
\hline Reliability & $86.897 \mathrm{a}$ & 0.000 & $\begin{array}{c}\text { Significant } \\
\text { at 1\% level }\end{array}$ \\
\hline Responsiveness & $48.610 \mathrm{a}$ & 0.000 & $\begin{array}{c}\text { Significant } \\
\text { at 1\% level }\end{array}$ \\
\hline Tangibles & $192.595 \mathrm{a}$ & 0.000 & $\begin{array}{l}\text { Significant } \\
\text { at 1\% level }\end{array}$ \\
\hline $\begin{array}{l}\text { Service } \\
\text { Responsibility }\end{array}$ & $148.818 \mathrm{a}$ & 0.000 & $\begin{array}{l}\text { Significant } \\
\text { at 1\% level }\end{array}$ \\
\hline Dimension & & 0.000 & \\
\hline Product & & & \\
\hline
\end{tabular}

\section{Source: Computed from primary data}

It is obviously identified that, there is a connection between overall satisfactions in travel agent services with Assurance, Reliability, Responsiveness, Tangibles, Service Responsibility and Service Product Dimension.

Table - 8

Amenities in Tourist Destination Factor

\begin{tabular}{|c|c|c|c|c|c|}
\hline $\begin{array}{c}\text { Tourist } \\
\text { destination }\end{array}$ & Mean & $\begin{array}{l}\text { Std. } \\
\text { Deviati } \\
\text { on }\end{array}$ & $\begin{array}{c}\text { Skewne } \\
\text { sS }\end{array}$ & $\begin{array}{c}\text { Kurt } \\
\text { osis }\end{array}$ & Rank \\
\hline $\begin{array}{l}\text { Drinking } \\
\text { Water }\end{array}$ & 3.07 & 1.156 & -0.437 & $\begin{array}{c}- \\
0.815\end{array}$ & VIII \\
\hline $\begin{array}{l}\text { Sporting } \\
\text { and } \\
\text { Recreation }\end{array}$ & 3.16 & 1.067 & -0.130 & $\begin{array}{c}- \\
1.042\end{array}$ & VI \\
\hline $\begin{array}{l}\text { Commercia } \\
1 \text { Tourist } \\
\text { Attraction }\end{array}$ & 2.75 & 1.112 & 0.039 & $\begin{array}{c}- \\
0.643\end{array}$ & XI \\
\hline Campsites & 3.22 & 1.294 & -0.053 & $\begin{array}{c}- \\
1.149\end{array}$ & IV \\
\hline Retail & 3.08 & 1.262 & -0.149 & $\begin{array}{c}- \\
0.838\end{array}$ & VII \\
\hline
\end{tabular}




\begin{tabular}{|l|c|c|c|c|c|}
\hline Banking & 3.18 & 1.130 & 0.057 & $\begin{array}{c}- \\
1.044\end{array}$ & $\mathrm{~V}$ \\
\hline Insurance & 3.02 & 1.101 & 0.136 & $\begin{array}{c}- \\
0.575\end{array}$ & $\mathrm{IX}$ \\
\hline Medical & 3.26 & 1.281 & -0.262 & $\begin{array}{c}- \\
0.778\end{array}$ & $\mathrm{III}$ \\
\hline $\begin{array}{l}\text { Emergency } \\
\text { Services }\end{array}$ & 2.87 & 1.182 & -0.319 & $\begin{array}{c}- \\
1.016\end{array}$ & $\mathrm{X}$ \\
\hline $\begin{array}{l}\text { Security } \\
\text { Services }\end{array}$ & 3.73 & 1.325 & -0.983 & $\begin{array}{c}- \\
0.118\end{array}$ & $\mathrm{I}$ \\
\hline $\begin{array}{l}\text { Behaviour } \\
\text { of co- } \\
\text { tourist }\end{array}$ & 3.39 & 1.198 & -0.272 & $\begin{array}{c}- \\
0.745\end{array}$ & $\mathrm{II}$ \\
\hline
\end{tabular}

Source: Computed from Primary Data

"Security Services" is the top ranked Amenities in Tourist destination Factor with a mean value of 3.73, followed by "Behaviour of co-tourist" (3.39), "Medical" (3.26), "Campsites" (3.22), "Banking" (3.18), "Sporting and Recreation" (3.16), "Retail" (3.08), "Drinking Water" (3.07), "Insurance" (3.02), "Emergency Services" (2.87), "Behaviour of local people" (2.84) and "Commercial Tourist Attraction" (2.75).

\section{FINDINGS OF THE STUDY}

This study is conducted for the purpose of analyze the tourists' satisfaction and their expectations and perceptions towards tourism services in Kodaikanal.

$>52.6 \%$ of the tourist are Female.

$>24.4 \%$ of the tourist belongs to the age group of 21 to 25 .

$>$ Majority of the tourist are married (55.2\%).

$>35.8 \%$ of the respondents have visited Kodaikanal for the first time.

$>35.3 \%$ of the tourists have used their own vehicle for make a trip in Kodaikanal.

> 25.6\% of the tourist have spent Rs.10,001 to Rs. 20,000 for travel to Kodaikanal

$>40.9 \%$ of the tourist is willing to visit Kodaikanal in season time.

$>24.4 \%$ of the tourist preferred star hotels for their staying.

$>64.2 \%$ of the tourist has utilized the services of travel agent.

$>53.92 \%$ of the tourist has utilized the services of tourist guide.

$>$ Housekeeping" is the top ranked services availed during the stay with a mean value of 4.38 ,

$>$ "Ticket Booking" is the top ranked services offered by travel agent with a mean value of 2.65

$>$ "Trustful and Friendly Services" is the top ranked services rendered by guide during visit factor with a mean value of (2.65)

$>$ Majority of the tourist have high level satisfaction towards food and accommodation services.

$>$ Lack of Parking Facility was ranked first by the respondents with the mean score of 66.032, followed by Traffic Jam (59.235), Lack of
Transport Facility (53.035), Higher Charges (50.209), Cheating/Theft (45.009), Poor Service (43.317), Land Scapes (40.791), Public Disturbances (36.491), Unclean environment (34.198) and Less availability of Tourist Guide (31.058)

\section{SUGGESTIONS}

In order to minimize the service gap, the following suggestions have been offered.

\section{To Service Providers}

* Cleanliness, hygienic conditions and satisfactory catering should exist at every place of tourist interest.

* Service providers should introduce modern equipments such as Travel guidance notification Kiosks, Traffic notification, parking availability Mobile Apps etc., more in numbers to support customer service and also to improve the efficiency, productivity and the quality of services.

* Take necessary steps for providing Klaus car parking system or automatic multilevel puzzle parking system to their customers

* Guides should know different languages which will help them to provide good service to the foreign tourists.

\section{To Government}

* The proposals of Rope Cars can be placed in sufficient area which recreates the tourist more.

* The Riding Tracks of cycles, Horses and Pedestrian walk ways should be proposed and maintained.

* Create more employment opportunities to youngsters by giving training in the field of tourist guides.

To Tourist

- The knowledge for tourists about the destination (Kodaikanal) should be must. The tourist should be medically fit to withstand the micro climate of the destination because Kodaikanal is a hill station based tourism area.

- The entries, recreational activities within the reserved area should be avoided.

- The tourist activities whether personal or commercial should not affect the nature of Kodaikanal in any way at any cause.

\section{CONCLUSION}

The tourism industry holds immense potential for the Indian economy and it can provide impetus to other industries through backward and forward linkages. Tourism is considered as a tool for economic development in India. Even though the service provider offers quality service to their customers, their Expectations are more than they perceived. The service provider must understand that Gap and take necessary implementation to offer quality service. 


\section{SCOPE FOR FUTURE RESEARCH}

* The study may be extended to other similar tourist Destinations in Tamil Nadu as well as in India

* In future, the study may focus towards Foreign tourism

* The research work may be extended to compare the services of Private and Government service providers.

\section{REFERENCE}

1. David.S.Moore, George.P. McCabe and Bruce Craig, "Introduction to the practice of Statistics: W/ Crunch It/ EESEE Access Card, Feb 7, 2014. ISBN-13: 9781464158933.

2. Gupta.S.P, "Statistical Methods" Sultan Chand And Company, New Delhi, 1900

3. Abas, shuib, Ahmad, Ayuob\&Norazirah, "An Evaluation of Service Quality From Visitors' Perspectives: The Case of Niah National Park",2013,retrieved from https://www.researchgate.net.

4. Babu.S (2010), "Eco - Tourism in the Mudumalai Wild Life Sanctury: A study", Southern Economist, Vol.No.49, No.6, July 2010, PP.52 - 54.

5. Department of Tourism., "A Land Enduring Heritage", India, Chennai

March, 1999.

6. Lalnunmawia.H, "Development and impact of tourism industry in India", retrieved from www.trcollege.netlarticles.

7. Mukhles Al-Ababneh, "Service Quality and its Impact on Tourist Satisfaction", Interdisciplinary Journal of Contemporary Research in Business, Vol 4, No 12, April 2013, pp - $164-177$, retrieved from www.ijcrb.webs.com

8. Perunjodi Naidoo, PrabhaRamseookMunhurrun\&JeynakshiLadsawut, "Tourist Satisfaction with Mauritius as a Holiday Destination", Global Journal of Business Research, Vol.4, No. 2, 2010, pp. 113-123, 2010.

9. Tran Thi Ai Cam," Explaining Tourists Satisfaction and Intention to Revisit NhaTrang, Viet Nam", Master Thesis submitted to NhaTrang University, Vietnam, May 2011, retrieved from http://hdl.handle.net/10037/3782. 